\title{
Effectiveness of SWOT and Kaizen in the Dominance of the Brain and the Hypocritical Personality of Physical Education Students
}

\author{
${ }^{1}$ Raed Abdulameer Abbas Al-Mashhadi* \\ ${ }^{1}$ Department of Sport Activity, Faculty of Materials Engineering, Babylon University, Iraq.
} Submitted 14 Mar 2019; Accepted in final form 29 May 2019.

\begin{abstract}
Background. Teachers including university professors insist on keeping up to date with the updating of students' information and developing their scientific potentials, through use of diverse teaching strategies. Objectives. Identifying on the brain dominance and the hypocritical personality for students, knowledge effect SWOT and Kaizen strategy in the brain dominance and the hypocritical personality for student and knowledge the strategies which achieve more development in the brain dominance and reduce the hypocritical personality for students. Methods. Two methods were used the descriptive method in measurement of the brain dominance and hypocritical personality, and the experimental method to determine the effectiveness of using the SWOT and Kaizen strategies in developing the brain dominance and reduce the hypocritical personality with fourth stage students in Faculty of Physical Education and Sports Sciences, sample of the research 60 students and duration of the procedures 14 weeks. Results. The SWOT and Kaizen are of the important strategies. Teachers should use it with their students to learn and develop brain dominance and reduction hypocritical personality for students. Conclusion. Brain dominance and hypocritical personality is centered within the moderate normative level of the students, SWOT and Kaizen strategies play a small role in development of the brain dominance and effective in reducing the hypocritical personality for students, there is no difference between the Kaizen and SWOT strategies in developing the brain dominance and a SWOT strategy is better than Kaizen's strategy for reducing students' hypocritical personality.
\end{abstract}

KEY WORDS: SWOT Strategy, Kaizen Strategy, Brain Dominance, Hypocritical Personality

\section{INTRODUCTION}

Academic achievement represents performance outcomes that indicate the extent to which a person has accomplished specific goals that were the focus of activities in instructional environments, specifically in school, college, and university (1) and it depends on all major cognitive, sensory and motor functions, including language, attention, learning, memory, perception, emotional processing, tool use, and fine motor control involve the processing capacities of both hemispheres (2). Identified importance of research in preparation of two strategies, namely SWOT and Kaizen strategy, to contribute in knowledge role of these strategies in enhancing the brain dominance and reducing the hypocritical personality for student. The literature of development of sports science requires modern strategies in solving psychological issues of sports education in two important subjects through development of the brain dominance and reduce the hypocritical personality and was based on the strategies of SWOT and Kaizen, where few studies on these strategies in field of sports and education. The researcher seeks to identifying on effect SWOT and Kaizen strategy in the brain dominance and the hypocritical personality for

*. Corresponding Author:

Raed Abdulameer Abbas Al-Mashhadi, Assistant Professor

E-mail: dr.raeed@yahoo.com 
student and knowledge the strategies which achieve more development in the brain dominance and reduce the hypocritical personality for students. It is difficult to doubt the importance of physical activity contexts for the development of friendships throughout childhood and youth (3) by reducing the hypocrisy of the person. The research samples are Students of the fourth stage in Faculty of Sport Sciences Babylon University for the academic year 20162017, Period from 4/1/2017 to 14/5/2017.

\section{MATERIALS AND METHODS}

The community identified students of the fourth stage of the Faculty of sport for the academic year 2016- 2017 for morning study of 92 students, and selected the sample randomly for 60 students and identified Division 2 at SWOT with 29 students and Division 3 for Kaizen strategy with 31 students. The sample constitutes $65 \%$ from research community. Students of the fourth stage males after exclusion of Division 4 with number 32 Students have been applied on them the pilot experiment, and the percentage of $50 \%$ from students of the fourth stage male and female after excluding Division 1 with number 28 students. Two approaches were used: the descriptive method to knowing the variables of research about students by approaches of comparative study and standard levels, and the experimental method by design the two equivalent groups of before and after the major experiment tests in implementation of the two strategies.

Research Scales. The brain dominance scales: The scale was prepared by (Salah Al-Ammar) of the sections and hemispheres of the brain, which was applied on students of physical education by "Ayed Karim 2016", consisting of 56 paragraphs, including 28 phrase for the right hemisphere and the same number for the left hemisphere and each of the 14 phrase that measure a part of the brain, and that the answer to each phrase is (yes or no) and the highest score obtained by the individual in the scale 56 degree and the lowest score 0 and characteristics thinking of each part and hemispheres of the brain. Left half (A, B) Right half $(\mathrm{C}, \mathrm{D})(4,5)$.

Section A External learning style: It is the upper left part of the brain characterized by thinking "Logical, Rational, Factual, Theoretic, Realistic, Analytical, Quantitative, Mathematical, Critical, Technic, Financial".
Section B Procedural Learning style: The lower left part from the brain it is characterized by thinking "Sequential, Organize, Detailed, Planner, Procedural, Controlled Conservative, Structured, Risk-Avoiding, Timely".

Section C Interactive Learning Style The lower right part from the brain it is characterized by thinking about it (Emotional, Kinesthetic, Symbolic, Artistic, Spiritual, Expressive, Feeling, Supportive, Verbal, Reader, and Writer.

Section D Internal learning style: The upper right part from the brain it is characterized by thinking "Visual, Holistic, Innovating, Imaginative, Integrative, Conceptual, Synthesizer, Simultaneous, Intuitive, SelfDiscovery, initiative, creative, risk- taking (6).

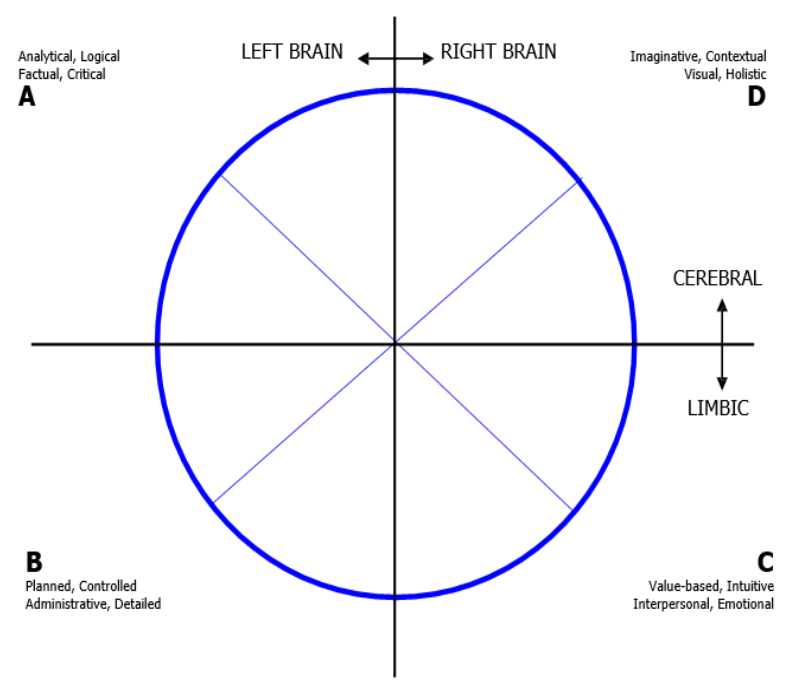

Figure 1. Herrmann's Learning Styles Model (7)

Hypocritical personality Scale: hypocrisy as a personal failing (8). In contrast from human vices and shortcomings that are shared by a select few, many people fall prey to hypocrisy. To remain on unremittingly faithful for personal principles is hard thing and even the best from us do not meet these ideals, "That hypocrites out to promote [their] own advantage at the expense of others (9). Thus, use the hypocritical personality scale prepared by "Khalid Jamal Jassim" was applied on students of the university consisting of 39 paragraph and the answer on the paragraphs is a multiple choice consists of 39 phrase one of the answers indicates to the high hypocrisy and the other to the little hypocrisy and the last no presence of hypocrisy, The highest score obtained by the individual in the scale 78 and the lowest score 0 and the satisfactory mean 39 . 
Statistical Analysis. Arithmetic mean, Standard deviation, Chi - square $\mathrm{x}^{2}$, T-test for interrelated sample, T-test for independent samples (10).

Field Research Procedures. Exploration Experience: A mini-exploratory experiment was conducted on 5-6/2/2017 on the students of the division 4 with number 36 students from the same stage of study and two lectures (one lecture per strategy) for knowing progress of procedures in terms of ease and difficulty the work As well as to determine efficiency of the assistance working team and the time in implementation of the strategies, as the time taken to answer on each scale from the research scale (brain dominance and personal hypocrisy) of 20-30 minutes and also determined the scientific basis of the two scales, and division of 1 excluded because it is a special division for female students and not for males student.

Research Groups Equivalent. On 12$13 / 2 / 2017$ and before application of the two strategies KAIZEN and SWOT, the equivalence of the two research groups was determined as an important matter should follow it in order to return the differences to the empirical factor. The two research groups should be equivalent in research variables to ascertain from the equivalence principle and dependence on t-test of the independent samples between division 2 and 3 between parts and hemispheres of the brain in the brain dominance scale and the hypocritical personality scale. The results showed the difference is no significant random between the two groups in the two research variables indicate to equivalent of two groups, as shown in Table 1.

Table1. Equivalent between the Two Groups Division 2 and Division 3 in the Research Variables

\begin{tabular}{|c|c|c|c|c|c|c|c|}
\hline \multirow[t]{2}{*}{ Brain sections } & \multirow{2}{*}{$\begin{array}{c}\text { Arithmetic } \\
\text { mean }\end{array}$} & \multirow[t]{2}{*}{$\begin{array}{l}\text { standard } \\
\text { deviation }\end{array}$} & \multirow[t]{2}{*}{$\begin{array}{c}\text { The degree of } \\
\text { freedom }\end{array}$} & \multirow[t]{2}{*}{$\begin{array}{c}\text { Level of } \\
\text { significance }\end{array}$} & \multicolumn{2}{|c|}{ T value } & \multirow[t]{2}{*}{$\begin{array}{c}\text { Statistical } \\
\text { significance }\end{array}$} \\
\hline & & & & & Calculated & standard & \\
\hline \multicolumn{8}{|l|}{ brain dominance } \\
\hline Division $2 \& 3$ & & & 58 & 0.05 & & 2.02 & Not significant \\
\hline A & (8.6) 8.3 & (1.5) 1.7 & (8.4) 8.1 & & 0.8 & & \\
\hline B & (8.4) 8.1 & (1.3) 1.8 & & & 0.8 & & \\
\hline $\mathrm{C}$ & (7.4) 7.1 & (1.5) 1.6 & & & 0.8 & & \\
\hline D & (7.5) 7.2 & (1.4) 1.6 & & & 0.8 & & \\
\hline $\mathrm{AB}$ & (17) 16.4 & (2.7) 2.7 & & & 0.9 & & \\
\hline $\mathrm{CD}$ & (14.9) 14.3 & (2.9) 2.7 & & & 0.9 & & \\
\hline $\begin{array}{l}\text { hypocritical } \\
\text { personality }\end{array}$ & & (45) 44 & & & & & \\
\hline Division $2 \& 3$ & (45) 44 & (3) 3.1 & 58 & 0.05 & 1.3 & & Not significant \\
\hline
\end{tabular}

Levels. Determined 3 standard levels for students of the College Sport with the following:

The levels of the intellectual imprint: The levels of the brain sections of those who get the mean of the 0-4.7 are a weak level. The number of students in this level 12-16 in each section, and from 4.8-9.5 is a moderate level and the most students in this Level 25-30 in all sections of the brain, and from 9.6-14 is a high level the number of students from 14-23.either two halves of the brain, the weak standard level of 0-9.3 and the moderate level of 9.4-18.7, and from 18.8 - 28 of standard high level.

The level of the hypocritical personality: Determined the first level from 0-26 which is the good standard because it indicates on a low level of hypocrisy among students. The number of students at this level reached 15 students by 0.25 , which is a small percentage of the research sample of 60 students , Either the moderate level, which was determined from 27-53, which indicates that the hypocrisy has a moderate level of students at this level 25 students by 0.42 indicate to the high rate, the last level was determine from 54-78 indicate to
High student hypocrisy, and the number of students at this level 20 students by percentage 0.33 higher than the first level, and this indicates to personality of students of physical education in The direction of hypocritical personality.

The main experiment was carried on 22$23 / 2 / 2017$ to $27-28 / 5 / 2017$ with $3 \& 1 / 2$ months, with number 28 educational units, 14 a lecture for the SWOT and the same number for the Kaizen, and determined by 7 objects about the brain dominance: (hemispheres, motion, perception, conceptual maps, intelligence and creativity, focus and attention, perception and 7 objects to reduce the hypocritical personality (religious values, family cohesion, selfinterpretation, Social interaction, self-confidence, psycho-social compatibility, sports journalist, and the subjects were implemented arrangement and after the completion of the subjects are repeated sequentially for the students' understanding importance of subjects in their academic, social and cognitive life, as shown in the experimental procedures in the experimental design adopted. Table 2. 
Table2. The used Experimental Design

\begin{tabular}{|lcccc|}
\hline $\begin{array}{l}\text { Test before experiment } \\
\text { Division 2 }\end{array}$ & $\begin{array}{c}\text { Strategies } \\
\text { brain dominance }\end{array}$ & $\begin{array}{c}\text { Test after the } \\
\text { experiment }\end{array}$ & $\begin{array}{c}\text { The implicit comparison in } \\
\text { one group }\end{array}$ & $\begin{array}{c}\text { Independent comparison between the } \\
\text { two groups }\end{array}$ \\
$\begin{array}{l}\text { hypocritical } \\
\text { personality }\end{array}$ & After -After \\
$\begin{array}{c}\text { Division 3 } \\
\text { brain dominance }\end{array}$ & KAIZEN & $\begin{array}{c}\text { hypocritical } \\
\text { personality }\end{array}$ & Before- After & Before- After \\
$\begin{array}{l}\text { hypocritical } \\
\text { personality }\end{array}$ & & $\begin{array}{c}\text { brain dominance } \\
\text { hypocritical } \\
\text { personality }\end{array}$ & Before- After & After \\
\hline
\end{tabular}

Procedures for the Implementation of SWOT Analytical Strategy and Strategy Kaizen. SWOT analytical strategy: S and W refer to elements of the strategy in the internal environment to which we mean connection with the individual, where $\mathrm{S}$ represents the strength elements, $\mathrm{W}$ is the weakness elements, either $\mathrm{O}$ and $\mathrm{T}$ Represent the strategic elements in the external environment that are outside the individual, including the environment and society, where $\mathrm{O}$ represents opportunities, while $\mathrm{T}$ represents Risks and threats. When studying any subject related by the brain dominance and hypocritical personality, The strengths and weaknesses points of each individual were shown and what opportunities and threats that the student faces from the external environment in the university, the family and In leisure and work is based on the model P.E.S.T, P political factors E economic factors, $S$ social factors, $T$ technical factors that affecting on students' life.

Kaizen Strategy: Kaizen is a Japanese word that carries two meanings, namely, "Kai" meaning "change" and "Zen" meaning for better (11), Kaizen means change towards the best, since any activity works the individual includes useful work and non-useful work Muda It is a Japanese word meaning non-beneficial work that does not give added value, which is called waste (The waste of production over the limit, waste of waiting, waste of operation, waste of transport, waste of movement, waste of storage, waste of repair or rejections), and the basis of the strategy Kaizen is the treatment of (Muda) This is done through the strategy steps used within the research areas that are associated with the brain dominance and hypocritical personality (By asking small questions to students about each object to exclude fear and gain interaction with the subject, attention to ideas, even if small to acquire new habits and skills, solving small problems according to the principle of public interest, aware of the small positions affecting others ignored), and It was confirmed in Kaizen's strategy is to divide the problem into its basic elements by using the fish structure diagram, as well as the steps of improvement, namely (classification), identifying the necessary and unnecessary things, and getting rid from the unimportant things, arranging things, cleaning the environment, Clean environment, calibration setting standards on the survival of things organized, neat and clean on the personal and environmental level, commitment is to do the right work as a daily approach.

\section{RESULTS}

Post-tests (After the main experiment). On $1-2 / 6 / 2017$, post tests were carried out to determine the value of the brain dominance and hypocritical personality after relying on the two strategies.

Comparisons between after and before the Major Experiment Tests in the Research Sample. Arrangements determine the significance to determine the significance of the development by using the two strategies, dependence on the t-test of the interrelated sample was based on the differences between the pre-test and the post-test Table 3. There is no significant significance between the after and before the major experiment tests, despite the high value of the arithmetic mean in the after-test about the before test in the brain dominance, this indicates the urgent need for intensive educational units. This indicates that the intellectual side requires longer periods and more units. This has led to an improvement in the after measurement the students, but it was not the required improvement. This indicates that the brain dominance is difficult to change because it is relatively fixed at the individual. Each student must be aware of his own brain dominance. This will help them to choose the appropriate job that suits their thinking, be managers in sports and educational institutions, trainers or accountants in companies, sports institutions, journalists, or sports and other professions that suit their according to their brain 
dominance. "Problem-solving is right-brain activities that the engineer shares with the artist, whereas applied design, project organization, materials assessment, and research are left-brain activities (7). Either in relation to the value of the arithmetic mean between after and before the major experiment tests in the hypocritical personality there was a significant significance between the two tests, which shows that the two strategies play an important role in reducing hypocrisy among students, through the steps of the strategies, as SWOT Analysis is an analysis method used to evaluate the strengths, weaknesses, opportunities and threats involved in an organization, a plan, a project, a person or a business (12). The Kaizen philosophy recognizes that there is always field for improvement, and everyone is encouraged to put forward small improvement proposals on a regular basis (13).

Comparisons between SWOT and Kaizen Strategies. To determine which of SWOT and Kaizen contribute more to development of the brain dominance and reduction of the hypocritical personality, dependence on the t-test for two independent samples was used for the after tests Table 4.

Table3. The Values of the Arithmetic Mean and t-test Value Standard and calculated for the Pre-and Post-test of the Two Groups in the

\begin{tabular}{|c|c|c|c|c|c|c|}
\hline \multicolumn{7}{|c|}{ Two Variables Research } \\
\hline Brain sections & $\begin{array}{c}\text { Test after the } \\
\text { experiment }\end{array}$ & $\begin{array}{r}\text { Test before } \\
\text { experiment }\end{array}$ & $\begin{array}{l}\text { Difference between } \\
\text { the two tests }\end{array}$ & $\begin{array}{c}\text { Value(T) } \\
\text { Calculated }\end{array}$ & $\begin{array}{l}\text { Value(T) } \\
\text { Standard }\end{array}$ & $\begin{array}{c}\text { Statistical } \\
\text { significance }\end{array}$ \\
\hline & $\begin{array}{c}\text { Arithmetic } \\
\text { mean }\end{array}$ & $\begin{array}{c}\text { Arithmetic } \\
\text { mean }\end{array}$ & & & & \\
\hline \multicolumn{7}{|c|}{ brain dominance } \\
\hline $\begin{array}{l}\text { Division } 2 \text { Strategy } \\
\text { SWOT }\end{array}$ & & & & & 2.04 & \\
\hline A & 10.1 & 1.4 & 1.5 & 1.7 & & No significant \\
\hline B & 9.5 & 1.1 & 0.9 & 1.1 & & No significant \\
\hline $\mathrm{C}$ & 8.4 & 1.2 & 1 & 1.2 & & No significant \\
\hline $\mathrm{D}$ & 9.1 & 1.5 & 1.6 & 1.5 & & No significant \\
\hline $\mathrm{AB}$ & 19.3 & 1.9 & 2.3 & 1.9 & & No significant \\
\hline $\mathrm{CD}$ & 17.4 & 2 & 2.5 & 2 & & No significant \\
\hline \multicolumn{7}{|l|}{$\begin{array}{l}\text { Division } 3 \text { Strategy } \\
\text { KAIZEN }\end{array}$} \\
\hline A & 9.3 & 1.2 & 1 & 1.2 & & No significant \\
\hline B & 9 & 1.1 & 0.9 & 1.1 & & No significant \\
\hline $\mathrm{C}$ & 8 & 1.1 & 0.9 & 1.1 & & No significant \\
\hline $\mathrm{D}$ & 8.4 & 1.3 & 1.2 & 1.3 & & No significant \\
\hline $\mathrm{AB}$ & 18.8 & 2 & 2.4 & 2 & & No significant \\
\hline $\mathrm{CD}$ & 16.4 & 2 & 2.1 & 2 & & No significant \\
\hline \multicolumn{7}{|c|}{ hypocritical personality } \\
\hline $\begin{array}{l}\text { Division } 2 \text { Strategy } \\
\text { SWOT }\end{array}$ & 33 & $£ 045$ & 12 & 4.1 & & Significant \\
\hline $\begin{array}{l}\text { Division } 3 \text { Strategy } \\
\text { KAIZEN }\end{array}$ & 39 & 444 & 5 & 3.3 & & Significant \\
\hline
\end{tabular}

Table 4. Values of the Arithmetic Mean and the Standard Deviation and the Values of (t) in the after-test between the Two Groups in the Brain Dominance and Hypocritical Personality

\begin{tabular}{|c|c|c|c|c|c|c|c|}
\hline \multirow[t]{3}{*}{ Brain sections } & \multicolumn{7}{|c|}{ Test (after- after) the experiment } \\
\hline & \multicolumn{2}{|c|}{ Division 2} & \multicolumn{2}{|c|}{ Division 3} & \multirow[b]{2}{*}{$\begin{array}{c}\text { Value(T) } \\
\text { Calculated }\end{array}$} & \multirow[b]{2}{*}{$\begin{array}{c}\text { Value(T) } \\
\text { Standard }\end{array}$} & \multirow[b]{2}{*}{$\begin{array}{c}\text { Statistical } \\
\text { significance }\end{array}$} \\
\hline & $\begin{array}{c}\text { Arithmetic } \\
\text { mean }\end{array}$ & $\begin{array}{l}\text { Standard } \\
\text { deviation }\end{array}$ & $\begin{array}{c}\text { Arithmetic } \\
\text { mean }\end{array}$ & $\begin{array}{l}\text { Standard } \\
\text { deviation }\end{array}$ & & & \\
\hline brain dominance & & & & & & 2.02 & \\
\hline A & 10.1 & 1.7 & 9.3 & 2.5 & 1.6 & & No significant \\
\hline $\mathrm{B}$ & 9.5 & 1.9 & 9 & 2 & 1.3 & & No significant \\
\hline $\mathrm{C}$ & 8.4 & 2.5 & 8 & 1.6 & 1.3 & & No significant \\
\hline $\mathrm{D}$ & 9.1 & 1.8 & 8.4 & 1.8 & 1.8 & & No significant \\
\hline $\mathrm{AB}$ & 19.3 & 3.1 & 18.8 & 2.7 & 1 & & No significant \\
\hline $\mathrm{CD}$ & 17.4 & 2.9 & 16.4 & 3.7 & 1.3 & & No significant \\
\hline $\begin{array}{l}\text { hypocritical } \\
\text { personality }\end{array}$ & 33 & 5.1 & 39 & 5.9 & 4.3 & & significant \\
\hline
\end{tabular}

\section{DISCUSSION}

"The brain is one of the most prominent examples for structural and functional differences between the left and right half of the body (14), and Thinking is a scalable framework which provides a lens for improved understanding and insight (15). Research results show no significant significance between SWOT and Kaizen in the brain dominance. This indicates that the two strategies are equally important imprint, either in terms of the hypocritical there are differences 
between two strategies for side of SWOT strategy. The researcher believes that the reason for this is realistic and simple through the dependence on the internal and external environment between the individual from side and the educational and life environment from the other side and introduction of the political, economic, social and technical fields in the current situation with the subject of hypocrisy affecting the personality of the student in the university, where SWOT analysis is an examination of an organization's internal strengths and weaknesses, its opportunities for growth and improvement, and the threats of external environment presents to its survival (16). By identifying the factors in these four fields, the organization can recognize its core competencies for decision-making, planning and building strategies (17). The main advantage of SWOT analysis is its simplicity have resulted in its continued use in both leading companies and academic communities (18). Either Kaizen strategy also has a good effect in reducing hypocrisy among students, especially with use of the fish scheme which some students interact with it. "The basic principles of Kaizen are: customer focus, continuous improvement, explicit recognition of the problem, teamwork, discipline development Self-service, providing continuous feedback to staff, and promoting staff development (19). These insights contribute to the understanding of individual variation of brain asymmetries and the mechanisms related to changes in cerebral dominance (20).

\section{CONCLUSION}

The arithmetic mean in the brain dominance and hypocritical personality is centered within the moderate normative level of the students, SWOT and Kaizen strategies play a small role in development of the brain dominance and effective in reducing the hypocritical personality for students, there is no difference between the Kaizen and SWOT strategies in developing the brain dominance and a SWOT strategy is better than Kaizen's strategy for reducing students' hypocritical personality.

\section{APPLICABLE REMARKS}

- A dopting teacher on the Kaizen and SWOT strategies as modern strategies in teaching for the various materials and sports skills for their important role in the educational process.

- On teachers seek to address the problems of the hypocritical personality and development the brain dominance for their students.

- Confirmation the teachers on the two strategies to reduce the student's hypocritical personality.

\section{REFERENCES}

1. Reimers AK, Wagner M, Alvanides S, Steinmayr A, Reiner M, Schmidt S, et al. Proximity to sports facilities and sports participation for adolescents in Germany. PLoS One. 2014;9(3):e93059. doi: 10.1371/journal.pone.0093059 pmid: 24675689

2. Hirnstein M, Hugdahl K, Hausmann M. Cognitive sex differences and hemispheric asymmetry: A critical review of 40 years of research. Laterality. 2019;24(2):204-252. doi: 10.1080/1357650X.2018.1497044 pmid: 29985109

3. Bailey R. Sport, physical activity and educational achievement - towards an explanatory model. Sport Soc. 2016;20(7):768-788. doi: 10.1080/17430437.2016.1207756

4. Özgen K, Tataroğlu B, Alkan H. An examination of brain dominance and learning styles of preservice mathematics teachers. Proc Soc Behav Sci. 2011;15:743-750. doi: 10.1016/j.sbspro.2011.03.176

5. Herrmann Global L. Exploring your mind: brain dominance according to the herrmann: Herrmann Global, LLC; 2018 [cited 2019]. Available from: https://exploringyourmind.com/br-herrmannquadrants.

6. AlGhraibeh AMA. Learning and Thinking Styles Based on Whole Brain Theory in Relation to Emotional Intelligence. OALib. 2015;02(05):1-14. doi: 10.4236/oalib.1101436

7. Hughes M, Hughes P, Hodgkinson IR. In pursuit of a 'whole-brain' approach to undergraduate teaching: implications of the Herrmann brain dominance model. Stud High Educ. 2016;42(12):23892405. doi: 10.1080/03075079.2016.1152463

8. Yankah EN. Legal Hypocrisy. Ratio Juris. 2019;32(1):2-20. doi: 10.1111/raju.12234 
9. Isserow J, Klein C. Hypocrisy and Moral Authority. J Ethics Soc Philos. 2017;12(2):191-222. doi: 10.26556/jesp.v12i2.224

10. Afthanorhan A, Nazim A. Introduction To SPSS2015.

11.Zailani S, Shaharudin MR, Saw B. Impact of kaizen on firm's competitive advantage in a Japanese owned company in Malaysia. Int $J$ Prod Qual Manage. 2015;16(2):183. doi: 10.1504/ijpqm.2015.071239

12.Kadar M, Popescu T, Moise IA, Muntean M. BLIS-brain Lateralisation Information System for Personalised Education Programmes Offered to Students of Engineering. Proc Soc Behav Sci. 2013;93:1065-1069. doi: 10.1016/j.sbspro.2013.09.331

13.GÜRel E. Swot Analysis: A Theoretical Review. J Int Soc Res. 2017;10(51):994-1006. doi: 10.17719/jisr.2017.1832

14.Gordian B. KAIZEN as a Strategy for Improving SMEs' Performance: Assessing its Acceptability and Feasibility in Tanzania. 2014.

15.Herrmann Global L. LLC: What is whole brain ${ }^{\circledR}$ thinking? : Herrmann Global, LLC; 2015 [cited 2019]. Available from: https://www.herrmann.com.au/what-is-whole-brain-thinking.

16.Schmitz J, Gunturkun O, Ocklenburg S. Building an Asymmetrical Brain: The Molecular Perspective. Front Psychol. 2019;10:982. doi: 10.3389/fpsyg.2019.00982 pmid: 31133928

17. Aarhan L. A Strategic Planning of Developing Student Information Management System Using SWOT Technique. J Univ Hum Dev. 2016;2(3):515-519. doi: 10.21928/juhd.20160203.28

18. Phadermrod B, Crowder RM, Wills GB. Importance-performance analysis based SWOT analysis. Int J Inf Manage. 2019;44:194-203.

19. Ghazinoory S, Abdi M, Azadegan-Mehr M. Swot Methodology: A State-of-the-Art Review for the Past, a Framework for the Future / Ssgg Metodologija: Praeities Ir Ateities AnalizE். J Busin Econ Manage. 2011;12(1):24-48. doi: 10.3846/16111699.2011.555358

20. O'Regan L, Serrien DJ. Individual Differences and Hemispheric Asymmetries for Language and Spatial Attention. Front Hum Neurosci. 2018;12:380. doi: 10.3389/fnhum.2018.00380 pmid: 30337864 